\title{
Transnational crime corruption, crony capitalism and nepotism in the twenty-first century
}

John McFarlane

The 1990s saw some of the most dramatic developments in modern history. The collapse of the former Soviet Union and consequent conclusion of the Cold War has changed the entire security architecture developed over the last fifty years. Other substantial changes in the political map in those fifty years include the emergence of new political and economic alliances, such as the European Union (EU) and the Association of South East Asian Nations (ASEAN); the establishment of the World Trade Organization (WTO); the proposal to establish an International Criminal Court, and the return of Hong Kong to Chinese sovereignty. Many nations have come to the conclusion that by surrendering some sovereignty they may benefit from the collective security and prosperity offered by cooperative arrangements with other states.

Superimposed on recent political and economic developments have been a number of other important changes, mostly derived from the spectacular developments in technology over the last decade. There has been a revolution in the way we handle information and communicate it to others. The globalisation of banking and commerce has changed the way international business is transacted. The speed and efficiency of international travel have changed our way of thinking as we have become citizens of the 'global village'. Our capacity to transport cargoes and provide services at the international level would have been inconceivable a few decades ago.

It is clear that the social, political and criminal environment in the twentyfirst century will be infinitely more complex than that of previous years. The end of the Cold War has marked the beginning of a period of dangerous chaos in many countries, where good governance has been replaced by anarchy (Russia and former Yugoslavia), apparent inter-communal harmony has deteriorated into inter-ethnic savagery and 'cleansing' (Rwanda and Bosnia), unemployment and poverty have increased dramatically (Indonesia and El Salvador), 
population disruption has reached serious proportions (Sierra Leone and China), religious and cultural schisms have given rise to extreme violence (Algeria and India), and many weak states have effectively failed (Somalia and Liberia). Other states, including some in the Asia Pacific region, have little chance of surviving without massive injections of aid, which they are unlikely to receive. Many of the pessimistic predictions made by Kaplan (1994), van Creveld (1996) and Huntington (1993) are proving to be accurate.

\section{Developments to transnational crime}

These changes have also opened up new opportunities for criminals operating at the transnational level. Trends such as easier travel, deregulated business transactions, and rapid technological change are likely to continue and become key causes of crime in the years ahead (Williams 1995a, 1995b). Crime, particularly at the transnational level, will become increasingly entrenched, widespread and complex. For example, Russia, which initially embraced the opportunity for change, was ill-prepared for the market economy and the social and political problems which followed the collapse of the previous system, so that the only people who appear to have benefited from the changes have been corrupt politicians and businessmen, regional warlords and the sophisticated and well-established mafiya groups. To say that Russia, a former 'superpower', is now on the verge of disintegration and collapse is not an exaggeration. Similarly, there is little doubt that greed, poor regulatory practices, corruption, crony capitalism, nepotism and criminal extortion were all significant contributors to the precipitation of the Asian financial crisis.

No country has been unaffected by these changes. The micro-states of the South Pacific have such limited resources that two small countries have generated, quite legally, up to 10 per cent of their national revenue from leasing facilities to the operators of international telephone sex lines. One South Pacific country, Tuvalu, with a population of only 9,500 people, is hoping to generate up to US\$65 million per year from the sale of its internet domain name, 'tv' (Pacific Islands Monthly, January 1998). Some of these countries are also providing offshore banking facilities which appear to have been exploited by transnational criminal organisations (Pacific Islands Report, 15 February 1999)

As a result of these and other changes in the international criminal environment, some transnational organised crime groups now have the capabilities and enough resources to challenge nation-states. Furthermore, transnational crime in its various manifestations can have a significant impact on international stability and security. Indeed, transnational crime is now widely accepted as part of the new security agenda in an increasingly complex and unstable global milieu. 


\section{Transnational and cross-border crime}

There is no internationally accepted definition of transnational or cross-border crime. André Bossard, Secretary-General of the International Criminal Police Organisation (INTERPOL) between 1978 and 1985, has written that elements constituting transnational crime are

- the crossing of a border either by people (criminals, fugitives on the way to commit a crime, or victims - such as in the case of traffic in human beings), or by things (firearms - such as when terrorists put arms on a plane before takeoff, techniques of money laundering). Objects used in the commission of a crime, such as drugs on carriers or in containers, or even criminal will may also cross borders (such as in computer fraud, when an order given from Country A is transmitted to Country B)

- international recognition of a crime. At national level, according to the principle 'nullum crimen, nulla poena sine lege' (no offence, no sanction without law), antisocial conduct can be considered as a crime only if there is a legal text providing for it. At international level, the act must be considered a criminal offence by at least two states. This recognition may result from international conventions, extradition treaties or concordant national laws (Bossard 1990:5).

In describing transnational crime, W.F. McDonald $(1995: 2,14)$ noted that, as with traditional criminology, the new field can be divided into two loosely linked sub-areas. First, there is transnational criminality, its causes, characteristics, social and geographic distributions, and effects. Second, new transnational and global institutions of crime control are being constructed. He added that

[t]he international regime being constructed to deal with the new transnational criminality represents a post-modern crossing of borders and assertions of particular values as universals... The borders to be crossed are not just the political boundaries of nations but legal, cultural, religious, and organizational boundaries within states.

Williams (1995b:6) describes 'transnational criminal organisations' as '...organised crime groups that have a home base in one state, but operate in one or more host states where there are favourable market opportunities'.

\section{The nature of transnational criminal activity}

In recent years, transnational crime has encompassed a very large number of criminal activities, ranging, for example, from art theft, computer crime, and illegal immigration, to piracy and crimes involving tourists. It operates at both the national and transnational levels. Supporting these criminal activities are 
specialist accountants, lawyers, financial advisers, bankers and chemists, as well as corrupt or compliant politicians, judges, government officials, law enforcement officers, members of the military, businessmen and even priests. The underlying motive for criminality is often simple-power and money. Transnational criminal organisations are diverse in structure, outlook and membership, but they pose formidable challenges for law enforcement at both the national and regional levels. One reason for this is their contemporary emphasis on loose networks rather than excessively formal and structured hierarchies (Williams 1995a).

\section{Future prospects for transnational crime in the Asia Pacific region}

Most of the current forms of criminality will continue to be of concern in the years ahead. However, a number of trends will encourage both new areas for criminal exploitation and new criminal enterprises. Probably the most significant threats to regional security and stability are the developing sophistication and globalisation of organised crime groups. Such groups are likely to increase their cooperation in areas of mutual interest—all forms of fraud, money laundering, cybercrime and corruption - which will continue to have a significant impact on regional economies. There is likely to be an increase and diversification in regional drug production, abuse and trafficking, and it is likely that insurgency groups in the region will become more dependent on crime-particularly drug production and trafficking - to finance their political campaigns.

In spite of the predicted expansion and diversification in crime within the region, it is highly unlikely that manpower or financial resources will be available to increase law enforcement resources at the same rate. The only realistic way in which regional law enforcement agencies will be able to effectively address future trends will be to recruit or train specialists to address the new and more sophisticated criminal threats and to place a higher priority on regional cooperation and intelligence-sharing on criminal matters.

\section{Corruption, crony capitalism and nepotism-the CCN factor}

Currently, corruption - like terrorism - is not recognised in international law as a crime in itself, but rather a term that describes a set of activities or behaviours that can have a very serious impact on the way in which decisions are made at numerous levels. In particular, corruption facilitates crime (at both the national and transnational levels) because it protects the secrecy of criminal activities, it diverts or compromises law enforcement resources and distorts the decisionmaking process.

Williams (1995b) notes that corruption is used to create a congenial environment in which criminal organisations can carry on their activities with 
impunity. It can range from the bribery of low-level law enforcement officials to ignoring particular criminal activities, to the offering of inducements to high-ranking government officials to acquiesce in the group's activities and to provide information about countermeasures by the government. Corruption can be used to neutralise individuals and institutions and can have deleterious effects on political culture and the social fabric.

Lupsha (1996:35) describes corruption as the ability to acquire information, take actions, acquire influence, access to rule makers and rule enforcers, and to penetrate opponents and targets of interest'.

The Queensland Criminal Justice Commission (CJC) notes that corruption is often motivated by greed and flourishes in an atmosphere of management neglect or where there are inadequate controls, checks and balances (1993). Transparency International (TI), an international anti-corruption nongovernment organisation established in 1993, use the term 'grand corruption' which covers 'massive payments that feed greed, not need' (Transparency International Australia 1995:7).

\section{Change and corruption}

In a paper written in 1968, Huntington suggested four reasons why a state's modernisation process increases the incidence of corruption. First, in many pre-modern societies, patronage, favouritism and the appropriation of public funds for personal use were acceptable and legitimate forms of behaviour. In some countries undergoing 'modernisation' these traditional practices have persisted. Second, the process of modernisation actually increases the potential for corrupt practices due to confusion over the issue of public and private domain during the change process. Third, people with new wealth used that wealth to buy power, often through bribery, from the nobles, landlords or bureaucrats who dominated the old order. Corruption became a technique for 'new men' to overcome their alienation from the political process and achieve political participation equivalent to their wealth and economic power. Finally, the modernisation process in newly independent nations or in newly developing countries goes hand in hand with the expansion of the state apparatus in the economic and social spheres. This invariably leads to an increase in bureaucratic control over economic activities, which tends to increase costs and reduce the profitability of business undertakings. More controls means more corruption.

In the same article, Huntington traces the links between corruption and political stability. When politicians are seen to be using financial power to secure support or to control the behaviour of individuals, or when politicians are seen to be enriching themselves from public funds rather than executing the public projects which they have promised, the decline in public confidence can open the way for coups, revolts and other forms of violent change (Huntington 1968). 
These analyses have some relevance to understanding the environment in which corruption operates in the Asia Pacific, particularly during periods of social or political instability.

\section{Corruption and transnational crime}

As Lupsha observes, transnational crime is not a new phenomenon, but

[w] hat is new is the scale of activity and the fact that organised crime now possesses tools once reserved for nation states. It is the dispersion of technology access, global mobility, expertise for hire, cheap easily acquired weapons of mass lethality, and the vast illicit capital and financial resources of modern organised crime permit it to threaten, rival, and undermine the stability of nation states, and to corrupt civil society...(1996:23-4).

Lupsha believes that underlining transnational criminal activity is the scourge of corruption, without which the criminals undertaking these transnational criminal activities would be far less successful. Criminals have been able to subvert politicians, judges, local government officials, law enforcement officers, businessmen and other influential people through threats, extortion, and blackmail. Probably the greatest incentive is greed coupled with an assumption that they will not be discovered, or if discovered, that they will be protected by others in power.

Souheil El Zein, the Director of Legal Affairs for INTERPOL, recently wrote that '[c]orruption is becoming an increasingly international problem which needs to be addressed by the entire community...The need for international action against corruption may never have been more acute than today' (El Zein 1998:28). The link between organised crime (both national and transnational) and corruption is of considerable importance.

\section{Financial resources to support corruption}

It is not difficult for sophisticated criminals to play on the greed of politicians and government officials, if only due to the enormous amounts of money generated by criminal activities.

The United Nations has estimated that global organised crime earns US\$1.1 trillion per year (Mosely 1995:4). According to the best estimates currently available, the annual value of the international illicit drugs trade exceeds US $\$ 400$ billion per year which, according to the United Nations International Drug Control Programme, is '...equivalent to approximately eight percent of total international trade' (UNDCP 1997:124). In any event, the international drugs trade is reported to exceed the value of the international oil trade and is exceeded only by the value of the international arms trade (The Economist 1997:19-21; Kraar 1988:27-38). Journalist Philip Knightly recently wrote that 'drugs are now too big a part of the global 
economy and the US and Australia have found, to their cost, that they cannot buck the market' (Knightly 1999:3).

In the same article, Knightly quotes Nobel Prize winner, Professor Milton Friedman, and former US Secretary of State, George Schultz, agreeing at a conference at the Hoover Institution at Stanford University, that 'the war on drugs [had] not only failed miserably [but] did not even have a moral dimension'. Friedman asked '[c]an any policy, however high-minded, be moral if it leads to widespread corruption?' (Knightly 1999:6).

In 1996, an International Monetary Fund working paper assessed international money laundering at about US $\$ 500$ billion, which represents 2 per cent of global GDP. Robinson (1996:13) claims that money laundering is 'the world's third-largest business'. A 1997 study by the Chulalongkorn University in Bangkok put the economic value of crime in Thailand during 1993-95 at between US\$24-32 billion, equivalent to 14-19 per cent of Thailand's GDP (Money Laundering Bulletin, February 1997:3).

With these kinds of financial resources at their disposal, it is hardly surprising that there is such a strong link between corruption and transnational criminal activities. The Russian Prosecutor-General, Yuri Skuratov, recently wrote to the Duma (the Russian Parliament) alleging that that the Russian Central Bank had secreted US\$50 billion (including IMF money) in the account of an offshore company established in Jersey, Channel Islands, apparently to hide Russian assets from creditors. Commenting on this matter, Dr Andrei Piontkovsky of the Russian Strategic Studies Centre was quoted as saying, '[i] t's not corruption. It's beyond corruption. It's complete collusion between money and power in Russia (Lewis 1999:20).

\section{The regional impact of corruption}

Recent revelations of high-level corruption in South Korea and Japan and alleged corruption in Indonesia and Papua New Guinea have emphasised the importance of international initiatives, such as those taken by the OECD. Clearly, such behaviour-most of which has international implicationsconstitutes a serious abuse of power. It bypasses the desirable standards of transparency and accountability in decision making and can lead to a substantial loss of confidence in the government of the day, and hence threats to the stability of the governing regime.

Since his fall from power, former President Suharto of Indonesia, and his family, have been under investigation for alleged corruption and nepotism. In 1996, a former President of the Republic of Korea, Chun Doo-wan, was convicted of corruption and his involvement in the 1980 Kwangju massacre. His successor, Roh Tae-woo, was also convicted of bribery allegedly amounting to some US\$650 million. 
Similar problems of serious corruption at the political level have occurred in recent years in Japan, Pakistan, China, Russia, Vietnam, Papua New Guinea and a number of other countries in the Asia Pacific region. This has led to popular movements against political corruption and nepotism, and against those who appear to have benefited accordingly (see Rashid and Islam 1997:18; Imbaruddin 1997:12-15; Tampipi 1997:16-18).

Pasuk attributes the 'wave of anti-corruption sentiment [which] has swept across Asia' to press publicity of corruption scandals, a new generation of politicians and lawyers who have spear-headed the attack on corruption, and the judiciary, for converting corruption charges into criminal convictions (Phongpaichit and Piriyarangsan 1966:iv, vi).

There have been major problems with crime and corruption in Australia. Over the last 30 years, there have been many Royal Commissions and other inquiries into organised crime, drug trafficking, paedophile activities and corruption, particularly at the police level. The best known of the recent inquiries in relation to police corruption were the Fitzgerald Inquiry in Queensland (Fitzgerald 1989) and the Wood Royal Commission in New South Wales (Wood 1997). Arising out of these Royal Commissions and Inquiries, several specialised agencies were established, such as the National Crime Authority (established in 1984), the New South Wales Independent Commission Against Corruption (1988) the Queensland Criminal Justice Commission (1990), the Western Australian Anti-Corruption Commission (1997) and the New South Wales Police Integrity Commission (1997). The Commonwealth Ombudsman exercises certain review responsibilities in relation to police corruption at the Commonwealth level.

\section{Corruption in international organisations}

On 16 March 1999, the European Union was plunged into crisis after the publication of a report into fraud and corruption forced the resignation of the President of the European Commission and all 19 Commissioners. The International Olympic Committee (IOC) has also been plagued by allegations of corruption and nepotism, resulting in serious damage to the reputation of the Olympic movement and recommendations of expulsion of several IOC members.

\section{International anti-corruption efforts}

On 16 December 1996, the United Nations General Assembly adopted a Declaration Against Corruption and Bribery in International Commercial Transactions. Although other international organisations, such as the OECD and the World Bank, have placed emphasis on combating bribery of foreign officials in business dealings, the impact of high-level corruption on good governance has only recently been acknowledged. Now corruption is of concern at the highest level of global policymaking (Walsh 1998:37-43). 
In 1994, the OECD issued a set of 'Recommendations on Bribery in International Business Transactions' which called on member governments to take effective action to deter, prevent and combat the bribery of foreign business officials. Such measures include reviewing their criminal, civil, administrative, tax, business accounting and banking laws. In October 1995, the OECD took the matter further with specific recommendations on the tax treatment of illicit payments (Bosch 1997). An OECD convention incorporating these proposals was signed in Paris on 17 December 1997 by 34 countries, together accounting for 70 per cent of world trade and 90 per cent of foreign direct investment. The Convention obliges signatories to criminalise bribery of foreign public officials and to cooperate in mutual monitoring of implementation. The Convention entered into force on 15 February 1999 with ratification by Bulgaria, Canada, Finland, Germany, Greece, Hungary, Iceland, Japan, Korea, Norway, the United Kingdom, and the United States (USAid Center for Democracy and Governance 1999).

\section{Good governance and anti-corruption}

In recent years much emphasis has been placed by bodies such as the World Bank, the IMF (see IMF 1998), and the Asian Development Bank on the concept of 'good governance', which the Australian Foreign Minister, Hon. Alexander Downer, has described as 'the effective management of a country's resources in a manner that is open, transparent, equitable and responsive to people's needs' (Downer 1997).

Larmour notes that "'governance" [is] a polite way of raising awkward issues of corruption, incompetence, and abuse of power'.

Good governance works by statistical comparison, the creation of league tables, visiting missions, international conferences and the emulation of best practice. It may be imposed by conditionality, but may also be self-imposed for fear of being left behind, or outside the club (1998:4).

Such institutions as parliamentary democracy, a free press, an independent judiciary and the role of ombudsmen all contribute to maintaining scrutiny over good governance by highlighting corrupt practices, incompetence and abuses of power. Where such institutions are either absent or weak, the opportunities for abuse are obviously greater.

\section{Planning for the twenty-first century}

In the rapidly changing environment previously described, transnational organised crime and corruption flourish. The efforts which Hong Kong has made to counter corruption, particularly since the establishment of the Independent Commission Against Corruption (ICAC) 25 years ago, have set an international standard for others to emulate. In recent years, the People's 
Republic of China has also placed a much higher priority on anti-corruption measures, which have resulted in intervention at the highest levels. The fight against corruption is a high priority for Premier Zhu Rongji.

Dealing with the threats of transnational crime and corruption requires a set of carefully crafted action plans. The formulation of such plans depends on local circumstances and contemporary events. It is important that specific forms of corruption are identified and dealt with specifically, rather than attempting to fight corruption as if it were a homogeneous phenomenon. In this way, it is possible to identify the forms of corrupt behaviour which have the greatest impact on the security and stability of the state. To do this it will be necessary to collect and analyse information to better understand the dynamics and mechanics of the different types of corrupt conduct. Then, through a systematic and scientific study of corruption, appropriate countermeasures can be developed that are relevant to the circumstances in which the corruption is identified.

\section{The response to transnational crime}

With the growing awareness of the increasing threat of transnational crime in recent years, initiatives have been taken at the national, regional and international level to deal with this problem. The United Nations, particularly through the United Nations International Drug Control Program, ${ }^{1}$ has been particularly active in counter-narcotics initiatives ${ }^{2}$ and in anti-corruption measures. ${ }^{3}$

The United Nations Convention Against Transnational Organised Crime, which was opened for signing at an international conference in Palermo, Italy, between 12-15 December 2000, was the culmination of six years of intensive effort by the Vienna-based United Nations Office of Drug Control and Crime Prevention, under the leadership of Pino Arlacchi. This process began with the Naples Political Declaration and Global Action Plan Against Organised Transnational Crime, which the United Nations General Assembly adopted in 1994, to deal with the increasingly insidious threat of transnational crime. The Convention will become an instrument of international law when 40 countries have ratified it. Ratifying the treaty is done when each country brings the terms of the Convention into force within its own jurisdiction. The United Nations expects this to take about two years.

The Convention, and its accompanying Protocols, oblige countries which ratify them to take a series of measures against transnational organised crime. The Convention establishes four specific crimes: participation in organised criminal groups, money laundering, corruption and obstruction of justice. The Convention seeks to align national laws in criminalizing acts committed by organised criminal groups. Under the Convention, this behaviour includes organizing, directed or aiding serious offences committed by an organised criminal group. It entails agreeing with one or more persons to commit a serious 
crime for financial or other material gain. To combat money laundering countries would have to require their banks to keep accurate records and make them available for inspection by domestic law enforcement officials. Anonymous bank accounts would not be permitted and bank secrecy could not be used to shield criminal activities. Corruption must be criminalised where there is a link to transnational organised crime. This includes offering, giving, soliciting and accepting any form of bribe, undue advantage or other inducement, where the proposed recipient is a public official and the purpose of the bribe relates to his or her official functions. The Convention will attempt to make extradition easier. It will also be easier for investigators and law enforcement officials to obtain evidence, conduct searches, obtain bank or corporate documents and question suspects. The convention contains a general basis for conducting joint investigations and measures for cooperation in special investigative procedures, such as electronic surveillance.

Accompanying the Convention are three Protocols. The first, titled Protocol Against the Smuggling of Migrants by Land, Sea and Air, addresses the problem of human smuggling. The second, titled Protocol to Prevent, Suppress and Punish Trafficking in Persons, Especially Women and Children, is concerned with sex trafficking. The third, titled Protocol Against the Illicit Manufacturing of and Trafficking in Firearms, Their Parts and Components, and Ammunition, deals with the illicit trade in firearms. In addition to the Protocols, the UNODCCP is working on an implementation strategy for a Global Program Against Corruption and a Global Program Assessing Transnational Organised Crime Groups: Dangerousness and Trends.

Initiatives taken on a regional level include

- the expressed desire of Ministers at the $3^{\text {rd }}$ ASEAN Regional Forum in Jakarta in July 1996 to consider 'the question of drug trafficking and related transnational issues, such as economic crimes, including money laundering, which could constitute threats to the security of the countries of the region'

- the ASEAN Ministers' Declaration on Transnational Crime, concluded in Manila on 20 December 1997

- the Manila Declaration on the Prevention and Control of Transnational Crime, concluded in Manila on 25 March 1998

- the Joint Communiqué of the $2^{\text {nd }}$ ASEAN Ministerial Meeting on Transnational Crime, held in Yangon, Myanmar, on 23 June 1999, including the adoption of the ASEAN Plan of Action to Combat Transnational Crime

- the ongoing work of the Asia-Pacific Group on Money Laundering

- the ongoing work of the International Criminal Police Organisation (INTERPOL) in the Asia-Pacific region 
- the ongoing work of regional police cooperation, through ASEANAPOL

- the establishment of the International Law Enforcement Academy in Bangkok in $1997^{4}$

- the establishment of the Philippine Centre on Transnational Crime in Manila in March 1999

- the proposal by ASEAN Ministers to consider establishing an ASEAN Centre for Combating Transnational Crime

- the establishment of an ASEAN Regional Forum Experts Group on Transnational Crime.

Finally, at the 'Second Track's level, in December 1996, the Council for Security Cooperation in the Asia-Pacific (CSCAP) ${ }^{6}$ decided to establish a Working Group on Transnational Crime, chaired jointly by Australia, the Philippines and Thailand. The Working Group has now met on eight occasions and has dealt with a very wide range of transnational criminal issues from the operational and policy perspectives, as well as assessing the relevance of such activities to regional security and stability.

In most circumstances, the capacity of a state to intervene operationally against transnational crime is limited to its own jurisdiction, nevertheless there are a number of strategies which can be employed at the national and regional levels to deal with this threat. The basic investigative tools apply transnationally, as they do nationally, but the emphasis is on sound liaison relationships, good information and intelligence exchanges, a sound understanding of the law enforcement systems in place in the other jurisdictions, a preparedness to consider mutual support and/or joint operational approaches, and professional trust.

There are a number of guidelines for dealing with transnational crime. These include the encouragement of greater legal and administrative compatability, accession to relevant conventions, and bilateral and regional cooperation.

The relationship between corruption and organised crime is the most dangerous, along with the illicit financing of political parties. Corruption is often the cornerstone of the activities of some criminal organisations. Its general effect on administrative departments (for example those delivering identity documents, customs services, tax offices) can facilitate all types of fraudulent activities including, particularly, international trafficking. It also protects criminals, since the officials who have been corrupted are frequently those who should be investigating the criminals' activities, or at least contributing to such investigations. Furthermore, the funds available to criminal organisations make it possible to offer bribes that are difficult to resist. It is their success in accumulating wealth that gives criminal organisations their power and makes them dangerous. 


\section{Conclusions}

There is little doubt that transnational crime, in its various manifestations, is on the increase in the Asia Pacific region. Transnational crime is becoming far more sophisticated, wide-ranging and serious in its impact on national and regional security and stability. The East Asian financial crisis and the internal disruption faced by several states have created circumstances in which it will be even more difficult for states to allocate the appropriate resources and expertise to counter the increasing threat of transnational crime, particularly if police resources need to be diverted to undertake public order tasks.

There is a close nexus between corruption and the rise of transnational crime-drug trafficking, firearms trafficking, money laundering, sex slavery and paedophilia, and many other types of criminal activity. The massive funds generated by transnational crime-particularly drug trafficking — can corrupt or suborn almost any system. Undoubtedly, the money so generated can be, and is being used, to corrupt politicians, judges, officials, police, and other people responsible for maintaining good governance and the rule of law. Corruption provides the lubricant that enables transnational crime to flourish, both within the states immediately affected and across jurisdictional borders. Transnational crime will never be contained, let alone overcome, unless there is a major global assault on the citadels of corruption.

Corruption is a major threat to democracy, economic and social development and good governance. It has been described as 'a moral and financial gangrene which stops society from functioning normally' (Transparency International and Worldaware 1994:3). It is an economic as well as a moral problem in that it discourages good business practices and, by creating a barrier against trade and investment, acts as an impediment to development. It raises the cost of goods and services. It is gives rise to waste and inefficiency through diverting tenders away from the best and most suitable supplier. The losses caused by corruption by far exceed the sum of the individual profits derived from it, because it distorts the whole economy. Finally, it taints the international reputation of the country concerned, making it more difficult to attract foreign investment.

Even more importantly, corruption is damaging because it strikes at the core of integrity and trust in the state and the way it operates, through undermining fairness, stability and efficiency. As an African Head of State once observed, "[y] oung people in my country now have as their role models the leaders who have made money from corruption. Corruption is destroying the future of our society' (Olesegun Obasanjo, quoted in Transparency International and Worldaware 1994:3). President Jiang Zemin has repeatedly called the fight against corruption in China 'a matter of life and death for the party and the state' (Lawrence 1998:10). 
In a corrupt environment, resources will be directed towards such nonproductive areas as the police, armed forces and other organs of social control and repression as the élite move to protect themselves, their positions and their material wealth. Laws will be enacted and resources otherwise available for socioeconomic development will be diverted into security expenditure (Transparency International 1995b:5).

Although transnational crime and corruption continue to present considerable threats to the security and stability of the countries of the Asia Pacific region, there are some grounds for optimism. At both the United Nations and regional levels, there is now a much greater awareness of the dangers posed by transnational crime in its various manifestations, and practical legal, law enforcement and political measures are being taken to deal with this problem. The fight against transnational crime has gained momentum over the last two years and cooperation at both the international and regional levels has probably never been better. This cooperation transcends the national, political, cultural and other divisions which so often make international cooperation difficult.

Similarly, as a result of greater regional cooperation against transnational crime, shared concern over such issues as the Asian financial crisis, and the problems in particular countries, there is a much greater awareness of the serious implications of allowing corruption, crony capitalism and nepotism to flourish. Almost every government in the region is taking these problems much more seriously, and there is certainly a groundswell throughout the region against corrupt practices and those who benefit from them. Realistically, there is an increasing awareness that international capital and aid could be denied to those countries that allow corruption to thrive.

Perhaps one of the few rays of hope to emerge from the Asian financial crisis is that each nation in the region is seriously reviewing the way its economic and social systems have been operating. The financial crisis exposed not only the weaknesses in financial regulation and fiduciary responsibility, but also the corruption and nepotism which contributed to precipitating the crisis. The opportunity has now presented itself to address the problems of the past and, above all, to introduce the transparency, accountability and political changes necessary to ensure that the likelihood of such problems arising again is minimised. Failure to grasp this opportunity will not bode well for the future security and stability of the Asia Pacific region. 


\section{Notes}

${ }^{1}$ See, for example, the United Nations International Drug Control Program World Drug Report, Oxford: Oxford University Press, 1997.

${ }^{2}$ The three principal initiatives taken by the UNDCP have been encompassed by three international Conventions: the Single Convention on Narcotic Drugs, 1961, whose purpose is to prevent and combat drug addiction by means of coordinated international action, using two complementary forms of intervention and control: prevention and repression; the Convention on Psychotropic Substances, 1971, which establishes an international control system for psychotropic substances which are generally produced by the pharmaceutical industry; and the Convention Against Illicit Traffic in Narcotic Drugs and Psychotropic Substances, 1998, which provides for comprehensive and innovative measures against drug trafficking, such as provisions against money laundering and against illicit activities related to precursor and essential chemicals and provisions for new methods of international cooperation such as transfer of proceedings, controlled deliveries and extradition of drug traffickers.

${ }^{3}$ The United Nations Declaration Against Corruption and Bribery in International Commercial Transactions, was concluded in New York in December 1996. This lead to the Organisation for Economic Cooperation and Development (OECD) Convention on Combating Bribery of Foreign Officials in International Business Transactions, which was concluded in Paris on 17 December 1997, and has since been the model for anti-corruption legislation in many countries, including Australia.

${ }^{4}$ The ILEA is sponsored by the United States Drug Enforcement Administration.

${ }^{5}$ The 'Second Track' is a dialogue process involving academic and other regional subject experts, as well as 'officials operating in their private capacities'.

${ }^{6}$ The current membership of CSCAP comprises Australia, Cambodia, Canada, China, European Union, Indonesia, India, Japan, Malaysia, Mongolia, New Zealand, North Korea, Papua New Guinea, Philippines, Russia, Singapore, South Korea, Thailand, Vietnam and the United States. It is likely that the Pacific Islands Forum, based in Fiji, will be granted observer status in CSCAP later this year. 